\title{
A flashback on the dawn of the meteorite impact/extinction theory
}

Jan Smit

Acta Palaeontologica Polonica 57 (4), 2012: 677-679 doi: http://dx.doi.org/10.4202/app.2011.0164

Presented are my personal recollections on some of the major contributions by the Alvarez groups to the birth and development of the meteorite impact/extinction theory.

Jan Smit [J.Smit@vu.nl], Department of Marine Geology and Sedimentology, Vrije Universiteit Amsterdam, de Boelelaan 1085, NL-1081 HV Amsterdam, the Netherlands.

This is an open-access article distributed under the terms of the Creative Commons Attribution License (for details please see creativecommons.org), which permits unrestricted use, distribution, and reproduction in any medium, provided the original author and source are credited.

FoF 